\title{
(RE)INTERPRETING EXOTIC PLANTATION FORESTRY IN 1920S NEW ZEALAND
}

\author{
MICHAEL ROCHE \\ School of People, Environment and Planning, \\ Massey University, Private Bag 11-222, Palmerston North. \\ M.M.Roche@massey.ac.nz
}

\section{Abstract}

Environmental historians who have contributed to the understanding of 'econationalism' in New Zealand and within the sub-area of forest history have shown how deforestation produced a preservationist impulse and an exotic afforestation response to timber famine. My own work, in partial contrast, has tended to explore the largely unsuccessful efforts at indigenous forest management for production in the nineteenth century as well as suggesting that the large-scale afforestation boom of the 1920 s and 1930s was a departure from the anticipated direction of state efforts when the Forests Department was established in 1919. Previously I have argued that the New Zealand State Forest Service under its first director L. M. Ellis initially favoured an orthodox state forestry model anchored on sustained-yield management of indigenous forests, and only later turned to large-scale exotic plantations, in order to forestall a projected timber famine by 1965 , and to buy time to enable the mechanisms for regenerating indigenous forests to be understood. This paper looks more closely at Ellis' initial statements about the role of plantation forestry and suggests that a partial change of interpretation is needed.

Keywords: state forestry, historical geography, environmental history, afforestation, New Zealand.

\section{Introduction}

This article grows out of some of the differences in, emphasis on, and interpretations of New Zealand's forest history that exist in the publications of New Zealand historians and my own writing as an historical geographer working in the field typically labelled 'environmental history'. This mostly rests on the significance of scientific forestry and of exotic afforestation in New Zealand in 
the 1920s. Previously I have argued that L. M. Ellis, ${ }^{1}$ as first Director of Forests in New Zealand (1920-28), initially favoured an orthodox state forestry model anchored on sustained-yield management of indigenous forests, and only later turned to large-scale exotic plantations, in order to forestall a projected timber famine by 1965, and to buy time to enable the mechanisms for regenerating indigenous forests to be understood. ${ }^{2}$ This interpretation has tended to be set aside by local environmental historians, who instead draw more direct connections between nineteenth-century private tree-planting and large-scale exotic afforestation in the 1930s and downplay the role of professional foresters in forest conservation.

In this paper I take the opportunity to reflect on these differences in a broader context and then look more closely than previously at Ellis' pre-New Zealand forestry influences and his initial statements about the role of plantation forestry in New Zealand in order to reassess whether it was the great departure from his professional training that I have previously asserted it to be. ${ }^{3}$ A later section then offers a counterfactual assessment of the direction of forestry in New Zealand had Ellis not been appointed. I conclude by suggesting a small but not insignificant repositioning over interpreting the course of deforestation, tree-planting, and forestry in New Zealand from the late nineteenth to the mid-twentieth century.

\footnotetext{
1 Ellis tended to sign himself as 'MacIntosh', which was sometime rendered as 'MacKintosh' in the press, but official documents suggest 'McIntosh' is legally correct and it is what he was hired under when he came to New Zealand. This latter point shaped the variation of the spelling I adopted for his entry in the Dictionary of New Zealand Biography. I can avoid this complication in the text by referring to him as L. M. Ellis, but McKelvey has tended to favour MacIntosh. Ellis' writings cited later in the paper have the spelling used on the actual document.

2 Michael Roche, 'The New Zealand Timber Economy 1840 to 1935', Journal of Historical Geography 16 (1990): 295-313; Michael Roche, 'The State as Conservationist, 1920-60: "Wise use" of forests, lands and water', in Environmental Histories of New Zealand, ed. Tom Brooking and Eric Pawson (Melbourne: Oxford University Press, 2002), 183-99.

3 This paper was originally presented in a session on forest histories at the New Zealand Historical Association conference held at the University of Otago in Dunedin in November 2013. As such, it preceded the publication of the Making a New Land: Environmental Histories of New Zealand by a few days. Some of the points raised in the closing chapter of that book address issues that are raised herein. For these reasons and because I have attempted a revisionist interpretation of some of my own work, I have left portions of the text in the first person, rather than creating a veneer of detachment by changing it to the third person and retro-fitting it to take Making a New Land into account.
} 


\section{Historical geography and environmental history}

Anglophone historical geographers can trace the recognisable origins of their sub-disciplinary specialism in geography at least back to the nineteenth century. One part of this intellectual heritage, shared with geography more generally, involved the study of the relationship between people and environment. Encountering US environmental history in the 1990s, historical geographers, myself included, were struck by the enthusiasm that these scholars brought to their endeavours and the extent to which many seemed to be unaware of historical geography's considerable and comparatively long-standing endeavours in related fields. Something of this combination of interest and indignation was captured in papers by leading UK, Australian and US historical geographers on the relationship between environmental history and historical geography. ${ }^{4}$ More recently and in a more conciliatory vein, R. M. Wilson, in the US context, has written of 'environmental historical geography' and a shared use of narrative by historical geographers and environmental historians. ${ }^{5}$ Meanwhile, M.V. Melosi has suggested that environmental historians have some 'generalized affection for geography' but also posed the question of whether any intellectual convergence between historical geography and environmental history is 'by blood or by marriage'. ${ }^{6}$

Some of my work has been described as environmental history and on other occasions I have been labelled as an environmental historian. In the latter instance this was a friendly enough invitation to attach myself to another group of scholars working on past environments. My own response has typically been to identify myself as an historical geographer, reasoning that I do not have to cease to be an historical geographer in order to do historical environmental research and that my initial exposure to geography means that the sorts of questions I ask are not the same as those posed by historians. For me, environmental history has two partially overlapping configurations, one as a subset of academic history and the other as an interdisciplinary arena in which are gathered historical geographers, historians, other historically inclined social scientists, and various paleo-oriented earth scientists.

\footnotetext{
4 Michael Williams, 'The Relations of Environmental History and Historical Geography', Journal of Historical Geography 20 (1994): 3-21; Joseph Powell, 'Historical geography and environmental history: an Australian interface', Journal of Historical Geography 22 (1996): 253-73; Craig Colten, 'Historical geography and Environmental history', Geographical Review 88 (1998): iii-iv.

5 R. M. Wilson, 'The past and future of environmental historical geographies', Journal of Historical Geography 43 (2014): 160-63.

6 M. V. Melosi, 'Environmental history and historical geography: an (often) excellent relationship?', Journal of Historical Geography 43 (2014): 163-67.
} 
Although the emphasis has changed over time, my historical geography writing, compared to the New Zealand environmental historians, has been a little more obviously theoretically informed. Though still largely based on narrative, it typically has a stronger concern for space and place (though less so than many human geographers with respect to space), and recently at least, has focused on shorter spans of time, mainly in the twentieth century. Importantly-and this imposes limits - it has also tended to concentrate on the role of state institutions and been particularly concerned with forests and land use. New Zealand environmental historians grounded in academic history might be contrasted as working on a wider suite of topics, though still largely 'rural', across larger time periods and displaying a greater interest in the attitudes, values, and activities of settler civil society.

But while as researchers we can bedeck ourselves with disciplinary badges, being located in New Zealand is to recognise that you are at a distance from the major clusters of researchers working in cognate areas. Indeed, in New Zealand there is only a comparatively small number of researchers even in the more expansive-style environmental history described above. Of course with distance and small numbers comes a certain freedom to select what to engage with from mainstream historical geography and environmental history. To what extent are my historical geography concerns grounded on fundamental subdisciplinary intellectual building blocks; or, are they more an assemblage of disciplinary predilections that are as much a matter of personal taste? This is a particular problem where you are dealing with small numbers of researchers and find yourself endeavouring to make a case that the historical geographers do it 'this way' and the environmental historians do it 'that way'. Research conducted along disciplinary lines can also reach out to bordering areas. For instance, in a different context I contrasted 'historical' and 'geographical' approaches to the study of World War I soldier settlement, while noting that this was not entirely a matter of disciplinary boundaries; some historians produced richly geographical accounts, and vice versa. ${ }^{7}$ The same applies to research into forest history internationally, where some environmental historians from academic history backgrounds have published in historical geography journals. ${ }^{8}$

\footnotetext{
7 Michael Roche, 'World War One British Empire discharged soldier settlement in comparative focus', History Compass 9 (2011): 1-15.

8 Greg Barton, 'Empire forestry and the origins of environmentalism', Journal of Historical Geography 27 (2001): 529-22; Brett Bennett and Frederick Kruger, 'Ecology, forestry and the debate over exotic trees in South Africa', Journal of Historical Geography 42 (2014): 100-109.
} 


\section{Empire forestry and New Zealand}

Although there is now a small New Zealand secondary environmental history literature about forests and forestry, it is useful to position local developments against a broader forest history backdrop. This can be done in a comparative fashion as well as in British imperial terms, although some aspects fall beyond these bounds and might be described under a 'global' heading. In comparative terms, New Zealand and Australia can be usefully studied. Both have similarly timed histories as settler societies, though their forest endowments were quite different, with New Zealand having a higher percentage of forest cover when European settlement commenced. The forests themselves contrasted in numerous ways, but one distinction of economic importance was the preponderance of indigenous soft woods in New Zealand and hardwoods in Australia, around which a reciprocal trade emerged. In both these countries, the expansion of colonial land settlement had priority as a land use. Initial views about inexhaustible forests gave way to timber famine concerns by the late nineteenth century. This story is also one shared to some extent by the United States and Canada. In both Australia and New Zealand, private tree-planting efforts identified the potential of a number of exotic species, and state afforestation efforts commenced in the late nineteenth century. Large-scale exotic plantation of forestry also became a feature of South Africa, but on a different politicoeconomic trajectory to Australia and New Zealand.

To adopt an imperial focus involves considering how and when forestry knowledge, officers, and materials all circulated around the Empire, especially from the 1870s to the 1930s. Forestry in British India to varying degrees formed the backdrop. A Madras forestry officer was brought to New Zealand in 1876 to advise on the setting up of a forestry department. Later, in the early twentieth century, Nancy-, Oxford-, and Edinburgh-trained foresters completed careers that took them through various parts of the Empire, including Australia and New Zealand. Although the first scientific forestry connections were between India and New Zealand, where German and French ideas and practices were used to illustrate the possibilities of forestry, progress was limited until the early twentieth century. This was still the case when colonial forester David Hutchins, who trained at Nancy and worked briefly in India before spending the rest of his career in southern Africa, visited New Zealand in 1915 to report on New Zealand forests. ${ }^{9}$ In southern Africa, Hutchins made his reputation through exotic afforestation. In still comparatively well-forested New Zealand,

9 Michael Roche, 'Colonial Forestry at its Limits: The Latter Day Career of Sir David Hutchins in New Zealand 1915-1920', Environment and History 16 (2010): 431-54. 
he instead devoted his attention to another part of the foresters' land management portfolio, in advocating demarcation of indigenous forests and their long-term sustained-yield management.

A backdrop to New Zealand debates were the differing interpretations of forestry in nineteenth-century British India, where, for some environmental historians, forestry was a set of imported and imposed French and German practices. The countervailing position is that state forestry in India emerged more distinctively out of exposure to local conditions and circumstances. ${ }^{10}$ Still further complicating the scene, for instance, is political scientist James Scott, who in Seeing Like a State outlines the emergence of scientific forestry in eighteenth-century Prussia and Saxony, paying close attention to how revenue and timber volume produced a particular emphasis whereby natural forests were managed until they came close to being plantations. His more expansive point was one of how a strong focus on a small number of factors made possible a high degree of control and manipulation, a point he extended to the late twentieth century state's control over broader areas such as urban planning, rural settlement, and agriculture. While Scott is clear that his forestry vignette is a metaphor for how state bureaucracies operate, his acknowledgement that 'the history of scientific forestry is important in its own right' has been perhaps too readily overlooked. ${ }^{11}$ A consequence is that what for Scott was a parable and a metaphor, for some has been read as a history of German forestry, where forestry is inevitably understood as plantation-based.

Other influences and incidents were more global; for instance, Pinus radiata, a native of California where it is known as Monterey Pine, attracted attention in Australia and New Zealand in the aftermath of the mid-nineteenth century gold-rush era as a candidate for large-scale afforestation efforts. Subsequently, large areas were also planted in South Africa. Appreciating that exotic treeplanting efforts extend back to the nineteenth century makes it is all too easy, but misleading, to conflate scientific forestry with exotic plantations in New Zealand. In other locales, as Brett Bennett demonstrates, there is further scope for actually looking more closely at production plantations as only part of the lexicon of scientific state forestry. ${ }^{12}$

10 Cf. Greg Barton, 'Empire forestry and the origins of environmentalism', Journal of Historical Geography 27 (2001): 529-22 and Ravi Rajan, Modernizing Nature: Forestry and Eco-Development 1800-1950 (Oxford: Oxford University Press, 2006).

11 James C. Scott, Seeing like a State (New Haven: Yale University Press, 1998), 11.

12 Brett Bennett, 'The origins of timber plantations in India', Agricultural History Review 62 (2014): 98-118. 


\section{New Zealand forestry historiography}

New Zealand's forest history can be interpreted with an emphasis on local initiatives, for instance with regard to the development of a preservationist sentiment or early tree-planting efforts, or else positioned within a wider framework of the expansion of British imperial forestry, which itself was slow to reach the white settler colonies of Australia and New Zealand; or pursued with an eye to local-global connections. While New Zealand on the eve of large-scale European settlement in 1840 was in percentage terms more forested than many other lands of overseas European settlement, it followed a similar trajectory of giving primacy to agricultural and pastoral land uses. Initial beliefs in the inexhaustibility of forest resources, as elsewhere, gave way within two generations to concerns about a coming timber famine. The range of introduced tree species and their growth rates attracted early attention and were distinguishing features of the New Zealand context. In New Zealand, as in Australia, forestry experts from British India advised on the implementation of scientific state forestry, on lines ultimately derived from French and German forestry practices mediated via India, albeit that little materialised out of these early efforts. ${ }^{13}$ The successful establishment of forestry departments in Australia and New Zealand had to wait until the first decades of the twentieth century, by which time appointments, such as L. M. Ellis and F. E. Hutchinson in New Zealand and Harold Swain in Queensland, meant that ideas from North American forestry science were also incorporated into local practices. ${ }^{14}$ But for most commentators, the distinguishing feature of forestry in New Zealand by the 1930s was, put simply, the establishment of large-scale exotic plantations.

New Zealand historians specialising in environmental history, understandably enough, have tended to see their topic entirely as a 'distinct sub-discipline of history' and have focused in some detail on the nineteenth century and the decades up to about $1920 .{ }^{15}$ They have directed attention to environmental anxiety and to the wider relationship between climate and settlement that can usefully add to present-day debates about global warming. ${ }^{16}$ Their major

13 Graeme Wynn, 'Pioneers, politicians and the conservation of forests in early New Zealand', Journal of Historical Geography 5 (1979): 171-88.

14 Michael Roche, 'Latter day 'imperial careering': L. M. Ellis - a Canadian forester in Australia and New Zealand, 1920-1941,' ENNZ: Environment and Nature in New Zealand 4 (2009): 58-77; Greg Barton and Brett Bennett, 'Edward Harold Fulcher Swain's vision of forest modernity', Intellectual History Review 21 (2011): 135-50.

15 James Beattie, 'Recent Directions in the Environmental Historiography of the British Empire', History Compass 10 (2012): 129.

16 James Beattie, 'Environmental Anxiety in New Zealand, 1840-1941: Climate Change, Soil Erosion, Sand Drift, Flooding and Forest Conservation', Environment and History 9 (2003): 379-92; James Beattie, 'Climate Change, Forest Conservation and Science: A Case Study of New Zealand, 1840-1920', History of Meteorology 5 (2009): 1-18, www.meteohistory.org/2009historyofmeteorology5/1 beattie.pdf. 
emphasis has been on the wanton destruction of the forest in the course of European settlement. This theme can be further divided. There has been research into the preservationist response to extensive and rapid deforestation. Associated with this is scrutiny of the links between indigenous flora and fauna, and a sense of colonial difference giving rise to the emergence of senses of identity. ${ }^{17}$ Other work has tracked the felling to exhaustion of forest remnants, but, by and large, historians have tended to pursue the settler response to a looming timber famine in the form of exotic tree-planting. ${ }^{18}$

Environmental historians have, however, paid some attention to the Royal Commission on Forestry of 1913. Paul Star suggests that its report 'condemned native forest not to total destruction but to non-production status' whereas 'until this time, the European conservationist trend had been towards indigenous production and integration with exotic production and exotic methods'. ${ }^{19}$ James Beattie and Paul Star also venture that the Royal Commission added weight to timber famine concerns so that 'to many foresters, it was therefore logical to meet future timber needs through extensive planting of exotics - and of Pinus radiata in particular - rather than of natives' ${ }^{20}$ In contrast, historical geographers Graeme Wynn and I have tended to examine legislative efforts, the role of the state, and attempts to implement schemes for the management of indigenous forests by professional foresters. ${ }^{21}$ Anticipating by a decade elements of this present exercise, Wynn has also reappraised the role he originally attributed to G. P. Marsh's ideas in Man and Nature in leading to the passage of the New Zealand Forests Act of 1874, now giving more weight to local actors. ${ }^{22}$ Beattie's Empire and Environmental Anxiety: Health, Science, Art and

17 Ross Galbreath, 'Displacement, conservation and customary use of native plants and animals in New Zealand', New Zealand Journal of History 36 (2002): 36-50; Paul Star, 'Native Bird Protection, National Identity and the Rise of Preservation in New Zealand to 1914,' New Zealand Journal of History 36 (2002): 123-36.

18 Paul Star, “'Doomed Timber": Towards an environmental history of Seaward Forest', in Landscape/ Community: Perspectives from New Zealand History, ed. Tony Ballantyne and Judy Bennett (Dunedin: University of Otago Press, 2005), 17-29; Paul Star, 'Tree Planting in Colonial Canterbury, 1850-1890', Environment and History 14 (2008): 563-82; Paul Star, ‘New Zealand's Biota Barons: Ecological Transformation in Colonial New Zealand', EHNNZ: Environment and Nature in New Zealand 6 (2011): 1-12; Paul Star, 'The contribution of Henry Matthews to tree culture in New Zealand 1896 to 1909', in Australia's Ever-changing Forests VI: Proceedings of the Eighth National Conference on Australian Forest History, ed. Brett J. Stubbs, Jane Lennon, Alison Specht, and John Taylor (East Lismore, NSW: Tankard Books, 2012).

19 Paul Star, 'Native forest and the rise of preservation in New Zealand (1903-1913)', Environment and History 8 (2002): 289.

20 James Beattie and Paul Star, 'State forest conservation and the New Zealand landscape: Origins and influences, 1850-1914', in Landscape/Community: Perspectives from New Zealand History, ed. Tony Ballantyne and Judy Bennett (Dunedin: University of Otago Press, 2005), 40.

21 Graeme Wynn, 'Conservation and Society in Late Nineteenth-Century New Zealand', New Zealand Journal of History 11 (1977): 124-36; Graeme Wynn, 'Pioneers, politicians and the conservation of forests in early New Zealand', Journal of Historical Geography 5 (1979): 171-88; Graeme Wynn, 'Destruction under the Guise of Improvement? The Forest 1840-1920', in Environmental Histories of New Zealand, ed. Tom Brooking and Eric Pawson (Melbourne: Oxford University Press, 2002), 100-116.

22 Graeme Wynn, 'On Heroes, Hero-worship, and the Heroic in Environmental history', Environment and History 10 (2004): 133-51. 
Conservation in South Asia and Australasia, 1800-1920 does, however, further concern itself with forestry professionals and indigenous forests in an imperial context. ${ }^{23}$

In 2002, the editors of Environmental Histories of New Zealand, Eric Pawson and Tom Brooking, observed that they were overtly combining historical and geographical approaches, further noting that the volume contained a wide range of disciplines. ${ }^{24}$ These distinctions between history and geography with respect to environmental history have become further blurred, for instance, in portions of Beattie's Empire and Environmental Anxiety. ${ }^{25}$

The temporal span of the work of the historians has been comparatively broad. This has advantages in terms of understanding longer-term trends. There are, however, implications in the choice of 1914 and/or 1920 as cut-off points for much of this research, particularly in terms of how to link tree-planting in the nineteenth century to the expansive plantations created by the state and companies in the 1920s and 1930s. On this point our interpretations differ. Elsewhere, I have suggested that by using 1914 as a break point, Beattie and Star in 'State Forest Conservation and the New Zealand Landscape' draw too direct a connection between the Royal Commission's recommendations for increasing state afforestation and the large-scale exotic plantation forests of the later twentieth century. ${ }^{26}$ In so doing, pivotal episodes are lost sight of, including the efforts of the eminent colonial forester David Hutchins to promote sustainedyield management of indigenous forests from 1915 to 1920. Ellis initially shared this focus as Director of Forests, which continued in the efforts of the New Zealand Forest Service in the 1940s to 1960s and culminated in the illfated beech scheme of the 1970s, later to reappear when the State Owned Enterprise (SOE) Timberlands West Coast proposed to resurrect sustained-yield beech forestry, but which was finally politically terminated in 1999. Little of this sequence of events, I would suggest, flows from nineteenth-century treeplanting efforts. ${ }^{27}$

On a number of occasions I have argued that paying close attention to treeplanting and identifying forestry as exotic plantation forestry is to misread the situation. Instead, I have suggested, the importance to professional forestry of sustained-yield management of natural forests in the nineteenth and early twentieth centuries needs to be kept to the fore. It was a core part of Ellis' 1920

23 James Beattie, Empire and Environmental Anxiety: Health, Science, Art and Conservation in South Asia and Australasia, 1800-1920 (Basingstoke: Palgrave Macmillan, 2011).

24 Eric Pawson and Tom Brooking, 'Preface', in Environmental Histories of New Zealand (Melbourne:

Oxford University Press, 2002), xii.

25 Beattie, Empire and Environmental Anxiety.

26 Roche, 'Colonial Forestry at its Limits'.

27 Roche, 'The New Zealand Timber Economy 1840 to 1935 '. 
report on forest conditions in New Zealand and amongst the principal tasks he outlined for the newly established State Forest Service in $1921 .^{28}$ It was also a point made vigorously and repeatedly by David Hutchins in opposition to popular and political enthusiasm for tree-planting as a solution to future timber needs, during his residence in New Zealand from 1915 to his death in 1920. ${ }^{29}$

The examination of New Zealand as a singular case, as opposed to placing New Zealand in some larger context, represents two contrasting research strategies, both of which have a valid place. Some of the published writing on the forest preservation theme in New Zealand seems to adopt the former approach, while my more recent efforts in terms of colonial forestry represent the other strategy. Links between forest preservation and nationhood in late nineteenth and early twentieth century New Zealand are deftly addressed by Paul Star and Lynne Lochhead in their chapter in Environmental Histories of New Zealand, while I have more closely considered the manner in which professional foresters spread across Australia and New Zealand in the early twentieth century. ${ }^{30}$ That said, it is not simply a case of historians undertaking detailed New Zealand-focused work and geographers working on a larger canvas; for instance, my Forest Policy in New Zealand: An Historical Geography 1840-1919 tends to focus, largely though not entirely, on the local, while Beattie's Empire and Environmental Anxiety places forest conservation within a French, German, Scottish and British imperial context. ${ }^{31}$

Since there is now, and has for some time been, some distance and differences between my own viewpoint and that of the historians interested in environmental history, I have decided to revisit some of my own assumptions and interpretations about forest history in New Zealand, especially as they seem to have limited purchase with environmental historians. More specifically, this involves in detail at the place of afforestation in Ellis' early statements about state forestry in New Zealand, especially the period from 1920 to 1925.

28 Appendices to the Journals of the House of Representatives [hereafter AJHR], C3A (Wellington: Government Printer, 1920).

29 Roche, 'Colonial Forestry at its Limits'.

30 Paul Star and Lynne Lochhead, 'Children of the Burnt Bush: New Zealanders and the Indigenous Remnant, 1880-1930', in Environmental Histories of New Zealand ed. Eric Pawson and Tom Brooking (Melbourne: Oxford University Press, 2002), 119-35; Michael Roche, 'Forestry as imperial careering: New Zealand as the end and edge of empire in the 1920s-40s', New Zealand Geographer 68 (2012): 201-10.

31 Michael Roche, Forest Policy in New Zealand: An Historical Geography 1840-1919 (Palmerston North: Dunmore, 1987); Beattie, Empire and Environmental Anxiety. 


\section{Ellis appointed as first Director of Forests, 1919}

A protracted series of largely behind-the-scenes manoeuvres in which farmerpolitician Sir James Wilson and Lands Department official E. Phillips Turner figured prominently, in conjunction with a public discourse in which the Royal Commission on Forestry of 1913 was prominent, paved the way for state forestry in New Zealand. Official and popular writings by the eminent colonial forester David Hutchins reinforced the case. Collectively these efforts led to the decision to appoint a professionally trained forester to head a forests department that was administratively separate from the Lands Department and responsible for both indigenous forests and exotic plantations. ${ }^{32}$ World War I delayed any progress, but in 1919 the position, along with that of Chief Inspector, was advertised in the United Kingdom. There were nineteen applicants for the Director's position, from which the London-based appointments committeecomprising Lord Lovat (a Scottish estate owner, a member of the Interim Forestry Commission, and later chairman of the British Forestry Commission (1919-27), R. L. Robinson, an Australian Rhodes Scholar and Oxford forestry graduate (1909), who was later technical commissioner and eventually long-time chairman of the British Forestry Commission, and A. G. Herbert (a New Zealand High Commission secretary-decided to shortlist only two men, L. M. Ellis and A. A. Dunbar Brander.

Ellis (1887-1941) at the time was an Advisory Forestry Officer for the Board of Agriculture in Scotland as part of the Interim Forestry Commission, forerunner of the Forestry Commission. During World War I, he had served in France as a Captain in the Canadian Forestry Corps. Earlier, he had graduated with a BSc in forestry from the University of Toronto, where the department was headed by the influential Bernhard Fernow. Subsequently Ellis was employed by the forestry department of Canadian Pacific Railways until he enlisted in $1916 .{ }^{33}$

Brander (1877-1953) was a Deputy Conservator of Forests in the Imperial Forest Service based in the Central Provinces of British India. He had graduated near the top of his class at the Royal Indian Engineering College at Cooper's Hill, the forestry section of which was headed by Dr William Schlich, an ex-Inspector General of Forests in India. Thereafter, Brander completed the standard practical courses in French and German forests. With twenty years of forestry service in

32 Roche, 'The New Zealand Timber Economy 1840 to 1935'; Michael Roche, 'McIntosh Ellis 1887-1941', Dictionary of New Zealand Biography, vol. 4 (Auckland: Auckland University Press, 1998): 157-58; Michael Roche, 'The Royal Commission on Forestry 1913 viewed from 2013', NZ Journal of Forestry 58 (2013): 7-11; Michael Roche, 'Edward Phillips Turner: The Development of a "Forest Consciousness" in New Zealand 1890s to 1930s', A forest conscienceness: proceedings 6th National Conference of the Australian Forest History Society Inc., 12-17 September 2004, August, Western Australia, ed. Mike Calver (Rotterdam: Millpress, 2005), 143-53. 33 Michael Roche, 'Latter day "imperial careering"'. 
India, including special expertise with working plans, he had been advised on health grounds to seek employment in a temperate climate. Brander had applied to the Interim Forestry Commission and for the Director's position in New Zealand with strong supporting references, including one from the Inspector General of Forests for India which attested to his technical ability. ${ }^{34}$ His longerterm reputation rested though on his book on wild animals of central India. ${ }^{35}$

At all events, Brander was unable to delay his return to India until after the interviews, and the panel of Lovat, Robinson, and High Commissioner Thomas MacKenzie were of the view that Ellis was 'excellently fitted for the position' ${ }^{36}$ In his application, Ellis stressed that he would be able to solve the 'forest problems' in New Zealand: this was a declaration of professional as well as personal confidence. These forest problems, he described in terms of forest utilisation, stabilisation of forest industries, 'forest renewal on unproductive lands', the raising of a national forest consciousness, improved forest revenues, tax reform for private forestry, forest land classification, and research. ${ }^{37}$ Indeed, the imprint of this list was evident in the forest policy directions he identified in 1920 (see below). Regarding themselves as expert natural resource managers, foresters such as Ellis shared some core professional values and skills, and advocated similar solutions to forestry problems. Thus, the extent to which the New Zealand environment, both social and biophysical, reshaped his forestry thinking is pertinent to some wider understanding of imperial forestry in the inter-war period. ${ }^{38}$

\section{French forestry's impression on Ellis}

During World War I, Ellis served in France with the Canadian Forestry Corps, and this first-hand exposure to long-established French forestry measures strengthened his appreciation of certain forestry principles and practices. These included the authority of French forestry officials even during wartime to control harvesting levels; the mixed farm and forest landscapes that matched land quality with land use, and which included populations of deer; and the realisation that French foresters played a wider role than just supplying

34 Archibald Brander, Working plan for the forests of the Bnajar Valley Reserve, [South]-Mandla Forest Division, Northern Circle, Central Provinces, for the period 1904-1935 (Allahabad: Pioneer Press, 1906); Archibald Alexander Dunbar Brander, Application for Director of Forests, F W1921 1, Archives New Zealand, Wellington.

35 Archibald Brander, Wild Animals in Central India (London: Arnold, 1923).

36 Thomas McKenzie to William Massey, 18 November 1918, SSC 5/15597, Archives New Zealand, Wellington.

37 L. M. Ellis, 17 November 1919, SSC 5/15597, Archives New Zealand, Wellington.

38 Roche, 'Forestry as imperial careering'. 
wood from state forests. ${ }^{39}$ As New Zealand forester Peter McKelvey later noted: 'It would have been a most insensitive forester who failed to appreciate the technical and aesthetic qualities in the managed beech forests of Normandy' ${ }^{40}$ Ellis admired the sustained-yield practices of French forestry, and in McKelvey's view, Ellis' proposals of 1920 for a 'new [New Zealand] Forest Service was based on exemplars which included the French system'. ${ }^{41}$ My own somewhat dissenting view is that Schlich's Anglo-German forestry ideas were at least as important in the choices Ellis finally put forward.

The point on which McKelvey and I agree is that sustained-yield management and multiple use of forests was at the core of Ellis' vision for the new forest department. Ellis would have been introduced to these ideas earlier, during his professional training under Fernow at Toronto, but he would not have seen them in mature application until he reached France. McKelvey also makes the point that timber scarcity concerns had underpinned initial German and French forestry practice in the seventeenth and eighteenth centuries, but that these ideas did not transfer that well to North America in the later nineteenth century, with the result that 'at the embryonic stage of American forestry [there] was too much emphasis on timber production without sufficient consideration of the costs involved', and that aesthetic forest conservation was overlooked. ${ }^{42}$ I agree about the selective transmission of forestry practices to New Zealand, while noting that Bennett has added to the complexity of the situation by posing questions about what 'French' or 'German' forestry actually meant in nineteenth-century British India. ${ }^{43}$ In my opinion, McKelvey underplays the sudden concurrent appearance in the late nineteenth century in North America, Australia, and New Zealand of deep concern about a timber famine. ${ }^{44}$

\section{Forestry in Great Britain-its impact on Ellis}

After demobilisation, Ellis took a position as an Advisory Forestry Officer with the Scottish Board of Agriculture. Forestry in Britain was acknowledged, particularly in the aftermath of World War I, as lagging far behind that of France

39 John Jeannery, 'The Impact of World War I on French Timber Resources', Journal of Forest History 22 (1978): 226-27.

40 Peter McKelvey, 'L. MacIntosh Ellis in France', New Zealand Journal of Forestry 34 (1989): 15.

41 McKelvey, 'L. MacIntosh Ellis in France', 16.

42 McKelvey, 'L. MacIntosh Ellis in France', 17.

43 Brett Bennett, 'A Network approach to the Origins of Forestry Education in India, 1855-1885', in Science and Empire: Knowledge and Networks of Science across the British Empire, 1800-1970, ed. Brett Bennett and J. Hodge (Basingstoke: Palgrave Macmillan, 2011), 68-88.

44 Michael Roche, 'Pests, Pines and Fires: Large Scale Plantation Forestry in New Zealand, 1897-1955', in Comparing Apples, Oranges, and Cotton: Environmental Histories of the Global Plantation, ed. Frank Uekötter (Frankfurt: Campus, 2014), 167-94. 
and Germany. I have not previously posed the question of what Ellis might have absorbed from his rather brief employment with the Board of Agriculture for Scotland, and in retrospect ought to have, for arguably it had an impact on his thinking about the future course of forestry in New Zealand. But in some other ways it does not: New Zealand, for instance, never adopted a Forestry Commission administrative structure. In my defence, I would observe that James' History of English Forestry, which I drew on at the time, while containing a useful and concise summary of events leading to the Forests Act of 1919 and the establishment of a Forestry Commission for the United Kingdom, as well as its efforts to develop private and state afforestation and timber production, and the difficulties encountered along the way, including a near-merger with the Ministry of Agriculture in 1924, does not include any details about the proposed scale of afforestation. ${ }^{45}$ The inability of Britain to provide for its own timber needs had been driven home during World War I. Varied responses took the form of a somewhat administratively independent Forestry Commission, the organisation of Empire Forestry Conferences from 1920 to co-ordinate an empirewide forestry policy, the establishment of an Empire Forestry Association, which published the Empire Forestry Journal (1922-46; thereafter the Empire Forestry Review until 1962), and the establishment of an Imperial Forestry Institute at Oxford University in $1924 .^{46}$

The Acland Committee established the longer-term goal of creating timber supplies in the United Kingdom sufficient to meet war-time requirements for three years. Translated into planting targets, this equated to the state afforesting $' 1,770,000$ acres of land previously unplanted (of which 1,180,000 acres) ${ }^{47}$ should be planted in 40 years [an average of 29,500 acres p. a.], and the whole in 80 years' ${ }^{48}$ In addition to this, three million acres of private forests would need to be retained and managed more productively. The Acland report also proposed land purchases of 22,000 acres per year to provide most of the land for planting. ${ }^{49}$ Although the planting programme did not fully eventuate, and took place after Ellis had arrived in New Zealand, access to Forestry Commission reports would have kept him apprised of its progress, and he heard first-hand Robinson's account of it at the Empire Forestry Conference in Ottawa in 1923. The scale of the British Forestry Commission plans can be compared to the more modest response the Royal Commission on Forestry in New Zealand of 1913 to

\footnotetext{
45 N. D. James, A History of English Forestry (Oxford: Blackwell, 1981).

46 Joseph Powell, 'Dominion over Palm and Pine: the British Empire Forestry Conferences 1920-1947', Journal of Historical Geography 33 (2007): 852-77.

$47 \quad 1$ acre is approximately 0.4047 hectares.

48 Forestry Commission, First Annual Report of the Forestry Commissioners (London: His Majesty's Stationery Office, 1920).

49 Forestry Commission, Sixth Annual Report of the Forestry Commissioners (London: His Majesty's Stationery Office, 1925).
} 
a projected timber famine by $1943 .^{50}$ The latter recommended a new annual planting target of only 6,415 acres, this still being an increase of two and a half times the 1911-12 annual planting of 2,566 acres.

To what extent was the trajectory of the British Forestry Commission a model for Ellis when it came to afforestation? This is a question I have not previously addressed. The significance of a commission rather than ministry/department model was also lost on me at the time. I now think it is reasonable to believe that the Forestry Commission's proposed large-scale and long-term afforestation plans lodged at the back of Ellis' mind as a legitimate strategy.

\section{Ellis in New Zealand}

Ellis' first task on arrival in New Zealand was to familiarise himself with local conditions and then to prepare a report which discussed the possible administrative structure of the department, the necessary legislative basis for forestry, and future steps. Thereafter, Ellis in 1920 listed the main thrust of forest policy in New Zealand under the following headings:

1. A simple forest act

2. A forest service

3. A forest development fund for development and demarcation

4. A progressive timber sales policy

5. Adequate facilities for technical education

6. State co-operation in private tree-growing

7. Administration of scenic reserves, national parks, and forested Crown land by the forest service

8. A forest products laboratory

9. A survey and inventory of the forest soils of New Zealand

10. An economic survey of the timber industry and timber-using industries

11. Administration of fish, bird, and game resources by the forest service. ${ }^{51}$

Of these, numbers 7 and 11 were never achieved by the State Forest Service or its successor the New Zealand Forest Service (1949-87), which also points to the importance of the somewhat separate preservationist themes studied by environmental historians in New Zealand. Number six would also seem to have been influenced by Ellis' prior experience in the United Kingdom.

50 AJHR, $\mathrm{C} 12,1913$.

51 AJHR, C3A, 1920. 
Previously, I have argued that Ellis gave central space to his timber famine calculations, and that his other initiatives make greater sense when clustered around this prediction of the Dominion being unable to meet its timber requirements by $1965 .{ }^{52}$ Initial work on indigenous growth rates and regeneration pointed to problems in this area as well. Even so, I argued, Ellis' early responses were quite in keeping with prevailing forestry canons of sustained-yield management of natural forests.

He initially proposed afforestation as part of a suite of forestry initiatives to supply regional timber needs. The acreage planted by the State Forest Service amounted to 1,381 (1921), 3,408 (1922), 2,862 (1,923), 7,207 (1924), and 11,051 (1925); that is, the Royal Commission on Forestry's recommended planting target was not reached until 1924. Writing to The Gum Tree, the magazine of the Australian Forestry League, in 1924 Ellis referred to lifting annual planting rates from 7,400 acres to 9,000-10,000 acres p. a. 'with the establishment in a year of two of a 20 thousand acre planting programme per year' ${ }^{53}$ In responding to Ellis' statement about plantation forestry in New Zealand at the 1923 Empire Forestry Conference, R. L. Robinson observed that afforestation 'operations in the United Kingdom approach pretty closely those described by Mr Ellis, except the conditions in New Zealand appear to be easier' ${ }^{54}$ This linking of the United Kingdom and New Zealand tends to reinforce the interpretation that the former offered a partial model for Ellis.

But, after 1925, Ellis mapped out a new pathway for exotic afforestation in New Zealand. Against the backdrop of timber famine, reinforced by the results of the National Forest Inventory of 1921-23, problems in finding the key to unlock the problems of indigenous regeneration, the speed of growth achieved by various exotic tree species, and-critically-the availability of areas of flat Crown land not wanted for agriculture, Ellis unveiled in 1925 a bold new planting scheme of 300,000 acres within 10 years (though at an average of 30,000 acres p. a. it was still of the same order of magnitude as Acland had proposed for the United Kingdom). This I have previously interpreted as a calculated risk, whereby Ellis, in keeping with his daring nature, responded expansively and beyond the narrower confines of his professional training to propose such an expansive planting boom. ${ }^{55}$ Now, I would seek to qualify somewhat this position.

52 Roche, 'The New Zealand Timber Economy 1840 to 1935', 304.

53 L. MacIntosh Ellis, ‘Forestry in New Zealand', The Gum Tree 8 (1924): 19.

54 Ronald L. Robinson, 'Great Britain', in Second British Empire Forestry Conference 1923 Proceedings and Resolutions with Brief Descriptions of Tours (Ottawa: F. A. Acland, Printer to the King, 1927), 129.

55 Roche, 'Latter day "imperial careering"'. 


\section{Ellis' early views about afforestation in New Zealand}

Ellis vigorously promoted the case for state forestry in print, but more usually through addresses before a range of sometimes sceptical farming interestgroups. Afforestation was not his initial concern - rather it was the bigger issue of a coming timber famine. Shortly after his arrival, Ellis addressed the A. \& P. Conference and led off by praising the afforestation effort:

Nowhere else in the world will be found such a magnificent mass of man-made forests. It is a wonderful achievement, and one that every citizen might well be proud of, and should see, for it represents sustained effort and great faith. To the Lands and Survey administration of the government is due to a large extent the credit for the formation of the great forest aggregation. ${ }^{56}$

He then turned to the pressing problems of world timber supply and the need for New Zealand to solve this problem or risk being dependent on imports, then passed on to the more politically challenging areas of the provisional state forests (areas Sir Francis Bell had recently removed from availability as a matter of course for land settlement), to protection forestry, and to improved efficiency in the sawmilling industry (which might have resulted in increased timber prices, as the State Forest Service charged more for milling rights). He couched his arguments in terms of the 'effective utilisation of all land areas' and emphasised that forestry was not in competition with other land uses, though the demarcation line between the two 'was not fixed and immobile' ${ }^{57}$ But, at this point, as far as afforestation effort was concerned, he restricted himself considerably to the view that co-operative profit-sharing arrangements would underpin future individual private and local-body planting, and that a more equitable system of forest taxation (citing American precepts) would encourage individual afforestation. The British Forestry Commission, it is worth remembering, also envisaged that local authorities and private plantings in the 1920-30 period would amount to 110,000 acres, or 73 per cent of the land afforested by the state. ${ }^{58}$

In 1921, writing for a farming audience, Ellis argued that the 'primary objective' of government forest policy was continuity of timber supply at reasonable prices, and the protection and utilisation of forests. Inches Campbell Walker, a shortlived appointee as Conservator of Forests in New Zealand in the 1870s, had

56 L. MacIntosh Ellis, 'Forestry', in New Zealand Forestry League Annual Report and Proceedings (Wellington: New Zealand Forestry League, 1920), 15.

57 Ellis, 'Forestry', 17.

58 Forestry Commission, First Annual Report of the Forestry Commissioners (London: His Majesty's Stationery Office, 1920), 15. 
made virtually the same remarks. ${ }^{59}$ However, while giving centre stage to the protection of 'indigenous forest capital', Ellis did venture that state plantations ought to produce 10 per cent of his predicted thousand million superficial foot ${ }^{60}$ timber consumption within a generation, of which private indigenous forests, as well as wood-lots and imports, would constitute 30 per cent. ${ }^{61}$

From almost his first acquaintance with New Zealand he was also prepared to relax some of his ideas about forestry practice:

[i]t is generally accepted in professional circles that timber-growing is the proper function of the State, but in New Zealand an exception may be made to this general rule. The extraordinarily long growing seasons and the remarkably sustained performance of many exotic trees result in really wonderful returns. Where else in the world are better wood-yields obtained than here, where from 75,000 to 200,000 superficial feet are secured for a thirty-year rotation of Pinus insignis? ${ }^{62}$

Thus, beyond the efforts of the state, private tree-growing was, in his view, 'a sound and remunerative business' ${ }^{63}$ Indeed, he regarded the private sector as having an important role in satisfying future timber demand, which he put at '150,000 to 200,000 acres of plantations' ${ }^{64}$ But, his next sentences, in the light of subsequent events, are especially interesting: 'is it possible to induce the establishment of this big cumulative area within a generation? It is well worth trying for ${ }^{\prime}{ }^{65}$ To achieve this goal, the State Forest Service would need to provide demonstration areas, education, instruction, and inexpensive growing stock.

In 1922, he still advocated 'creating a self-supporting timber supply basis by the reasons utilisation of our God-given forest resources', though he did see a place for 'the dedication to Tree-farming of all forest-bearing Crown lands chiefly valuable for forestry'. ${ }^{66}$ In addressing the New Zealand Forestry League, an elite, special-interest group that had agitated for the creation of a separate forest department, he spoke of protection and production forestry, a state planting effort of about 3,000 acres p. a., and efforts to encourage private tree-planting.

59 Inches Campbell Walker, 'On State Forestry: Its Aim and Object', Transactions and Proceedings of the New Zealand Institute 9 (1877): 187-203.

60 One superficial foot (colloquially termed a 'super foot') was a board the equivalent of 12 " x 12" x 1" and equal to 0.0236 cubic metres. In North America the term 'board foot' was used instead of superficial foot.

61 L. MacIntosh Ellis, 'Forestry in New Zealand', NZ Journal of Agriculture 22 (1921): 88.

62 Ellis, 'Forestry in New Zealand', 88. At this time Pinus radiata was still termed Pinus insignis in New Zealand

63 Ellis, 'Forestry in New Zealand', 89.

64 Ellis, 'Forestry in New Zealand', 89.

65 Ellis, 'Forestry in New Zealand', 89.

66 L. McIntosh Ellis, 'Forestry Facts', The Forest Magazine [New Zealand] 1 (1922): 6. 
At this point, prior to the availability of the results of the National Forest Inventory, the main emphasis was still on effective control and management of indigenous forests.

In 1924, before the conference of the New Zealand Farmers' Union, Ellis summarised progress in state forestry in New Zealand by reference to the tasks he had outlined in 1920. He also spoke on changes to land tax recommended by the Royal Commission on Land and Income Tax which would stimulate private afforestation. More important, though not overstated, was his announcement of summary data from the National [indigenous] Forest Inventory which confirmed that annual consumption was in excess of the 'annual growth increment' and would result in exhaustion in 35 to 40 years (1959-64). ${ }^{67}$

But at some point around 1924-25 Ellis changed tack, now putting more energy into afforestation; in a special interview for New Zealand Life entitled 'New Zealand - The Timber Farm of Australasia', he extolled, with unintended hyperbole, the 'ideal soils of the great "Inland Empire" of the pumice lands', the speed and volume of wood growth, low fire risk, and wider market possibilities thinking especially of Australia, perhaps informed by his attendance at the 1923 Empire Forestry Conference.$^{68}$ It is of note that at this point, he was still advocating not only Pinus radiata, but also Ponderosa Pine, Corsican Pine, Douglas Fir, redwoods, other unspecified pines, and Macrocarpa as species for use in afforestation. He also admitted to a new influence on his thinking:

[w] ith the possible successful establishment of a pulp and paper industry a new market for coniferous softwood intermediate fellings will be available. I was recently informed by the best of paper making authority that that day is near at hand. ${ }^{69}$

The individual in question was William Adamson, representative of the British paper-making machinery firm Walmsley \& Co. On a visit to Australia and New Zealand, Adamson fired Ellis with the possibilities of growing plantation forests in New Zealand for a future pulp and paper industry; remember that at this time it was unknown if Pinus radiata would be suitable for papermaking. Thereafter, Ellis, while not disavowing the centrality of sustained-yield management of indigenous forests and the role of protection forestry, became more interested in the extended possibilities of exotic afforestation work in New Zealand. This included the afforestation of formerly cut-over forest and, significantly, other lands not suitable for agriculture.

67 L. McIntosh, Ellis, 'State Forestry in New Zealand', New Zealand Life and Forest Magazine 3 (1924): 9.

68 L. MacIntosh Ellis, 'New Zealand-The Timber farm of Australasia', New Zealand Life 4 (1925): 7.

69 Ellis, 'New Zealand-The Timber farm of Australasia', 7. 


\section{5: A 300,000-acre planting boom announced}

In 1925, in reviewing five years' State Forest Service activity, Ellis struck a very positive note, but did acknowledge that kauri was nearly exhausted, that kahikatea would last twenty years, and rimu supplies about 40 years. ${ }^{70}$ On the basis of some quite detailed calculations about future timber consumption, he predicted 'virgin softwood resources would be exhausted by $1965-70^{\prime} .{ }^{71}$ To some extent this was an admission of defeat over sustained-yield management of the indigenous forests, though elsewhere Ellis suggested it was a matter of searching for the key to natural regeneration and of using plantations as a source of timber until the former was understood and incorporated into State Forest Service indigenous forest management practices. But his response was undoubtedly bold: 'at present [1925] there are 63,000 acres of State plantations. It is recommended that this area be increased to 300,000, formation to be completed by the year 1935' [original italics]. ${ }^{72}$ If evenly distributed across the 10-year period, this amounted to 30,000 acres p. a., or three times the amount of planting that Ellis had previously contemplated.

Ellis was planning a threefold increase in the annual planting rate, but this self-assurance was not entirely without foundation. The efforts of nineteenthcentury tree-planting enthusiasts, and the more systematic efforts of the Forestry Branch of the Lands Department (1897-1919) which established 63,000 acres of state plantation, had shown that Pinus radiata grew very rapidly in New Zealand and was suitable for other than just fruit crates, as was originally thought. Ellis also had the example of some afforestation companies planting in the central North Island after 1923, even though he remained sceptical about some of their claimed growth rates and harvest predictions. He asked the Conservator of Forests for Auckland to provide him with detailed information about the new afforestation companies set up after 1924, asking that immediate action' be taken against 'extravagant statements' ${ }^{73}$ The State Forest Service had also managed to markedly reduce the cost of establishing plantations from $£ 8$ to $£ 9$ per acre to less than $£ 2$ by $1923 .{ }^{74}$ This point was important as it overcame one of the classic reservations of foresters, such as Schlich, about placing too much emphasis on exotic afforestation. Pinus radiata seed was readily procurable, and likewise, crucially, there was flat Crown land available that was easy to plant and not sought after for pastoral farming, in the form of the cobalt-deficient

\footnotetext{
$70 \quad A J H R, \mathrm{C} 3,1925,7$.

71 AJHR, C3, 1925, 7.

72 AJHR, C3, 1925, 7.

73 Ellis to Conservator of Forests, Auckland, 23 July 1924. Private Afforestation companies - General 1924-

1929. BAAX A457 1124 b 29/1/0/ Part II, Archives New Zealand, Auckland.

74 AJHR, C3, 1925, 5.
} 
'bush-sick' lands of the central North Island. One consequence of this was the concentration of planting effort at Kaingaroa State Forest, which grew to 329,065 acres gross area by 1934 , and comprised 55.1 per cent of state plantations. ${ }^{75}$

Some sense of the extent to which Ellis was departing from mainstream forestry tenets can be gauged from the reaction of foresters in New Zealand (and Australia) for the Empire Forestry Conference in 1928. The delegates from across the Empire toured the country in October-Ellis had resigned in March. The Report of the Committee on New Zealand stressed the importance of 'extending silvicultural research' in indigenous forests while noting the lack of forward planning as far as exotics were concerned past $1935 .^{76}$ The latter was required to 'provide a regular series of age classes and ensure the working of the plantations on a sustained yield basis' ${ }^{77}$ Furthermore, it was 'obvious that thinnings are urgently required' and that these might ultimately be used for pulpwood. ${ }^{78}$ There was also concern over insect or fungal damage, and the threat posed by fire.

Ellis eventually informally suggested a five million-acre plantation estatebeing the amount of forest-bearing land not suitable for pastoral farming. His announcement of an expanded planting effort in 1925, while much smaller still, represented a new scale and direction for the State Forest Service, one that was the source of some criticism from foresters, who inspected the state forests in the course of the Empire Forestry Conference in 1928. This is the important point of difference between the environmental historians and me. Even if it appeared at a national level that the State Forest Service was just following along the lines suggested by amateur tree-planters since the nineteenth century, this was not actually the case; indigenous forest management came back onto the political agenda from 1915 to 1925. Thereafter, the afforestation initiative, particularly as Pinus radiata became the dominant tree species, was one that departed somewhat from the European forestry script.

\section{Another appointee as director of forestry: A counterfactual forestry narrative}

Ellis was both a colourful personality and a compelling advocate who brought a particular bundle of professional forestry training and experience to bear in New Zealand (some of which he later modified in the light of local experience,

75 AJHR, C3, 1934, 6

76 Empire Forestry Conference, Summary Report, Resolutions and Reports of Committees. Appendix 3,

New Zealand (Canberra: H. J. Green, Government Printer, 1928), 35.

77 Empire Forestry Conference, Summary Report, Resolutions and Reports of Committees, 36.

78 Empire Forestry Conference, Summary Report, Resolutions and Reports of Committees, 36. 
for instance over forest grazing and forest game). If he had not been appointed but instead the other short-listed candidate Dunbar Brander had taken up the position, what might forestry in New Zealand have looked like? The following paragraphs identify a possible trajectory for forestry in New Zealand with Brander as Director of Forests. ${ }^{79}$ Even if Brander had not accepted the position, it seems likely that, with any interview process being held by the New Zealand High Commissioner in London assisted by the British Forestry Commission staff, an alternative successful appointee would most likely have been in the classic British colonial forestry type. Thus, a forester would typically have graduated BA, DipFor (Oxon.) and have done a finishing tour of German or French forests, before joining one of the colonial forest services, most likely in India, and working up the ranks to conservator.

As Director of Forests in New Zealand his report on forest conditions in New Zealand would have been similar in many respects to Ellis', but with some differences in emphasis. ${ }^{80}$ For instance, he might have favoured a Forestry Commission administrative model, one that Ellis also considered, but set aside. This had been adopted in Victoria and New South Wales, but while a committee of independent expert natural resource managers making decisions about allowable cuts in the national interest without regard to political expediency rested well with the colonial forestry mentality, it did not play out so well in settler states, such as Victoria. A frustrated Owen Jones departed in 1925 after five years as chair of the Victorian Forestry Commission to join New Zealand Perpetual Forests, while in Western Australia, even in the absence of a commission structure, the autocratic and inflexible Conservator of Forests, C. E. Lane Poole, clashed so badly with politicians that he resigned his position. ${ }^{81}$ In any case in New Zealand, Phillips Turner, virtually the sole advocate for forestry within the public service, was a long-serving bureaucrat who by temperament and outlook would have favoured the departmental model for forestry. Sir Francis Bell, the Commissioner of-the present day equivalent of Minister for-State Forests also preferred the departmental model and the unusual arrangement imposed on Ellis, whereby he was Director of Forests on a three-year renewable contract responsible to the Cabinet and not part of the permanent public service, with a Secretary of Forestry, a position filled by Phillips Turner, as

79 Archibald Dunbar Brander retired as Conservator of Forests in the Central Provinces of India in 1923. Thereafter he took over as factor of the Pitgaveny estate, Scotland, which had passed to his elder brother. This involved the management of forests and plantations, but marked the end of his time as a professional forester. His Wild Animals in Central India went through a number of editions and he continued to make shorter contributions to the Journal of the Bombay Natural History Society into the late 1920s. Dunbar Brander shares a chapter with his brother James in Michael Brander's The Big Game Hunters (New York: St Martin's Press, 1988).

80 Mary Sutherland was the first woman forestry graduate in the British Empire in 1916.

81 John Dargavel, The Zealous Conservator: A Life of Charles Lane Poole (Crawley, WA: University of Western Australia Press, 2008). 
the administrative 'head'. This model would doubtless have remained in place, regardless of appointee. It was, however, still an administrative model supported by Sir William Schlich, the doyen of imperial forestry.

In some areas Director ' $\mathrm{X}$ ' would probably not have matched the quality of Ellis' solutions, for instance regarding fire control..$^{82}$ In other respects, the emphasis would have been different. Director ' $\mathrm{X}$ ' would arguably have:

- been less dramatic in defining a timber famine by 1965

- used the 1913 Royal Commission on Forestry's revised planting targets, and those of the British Forestry Commission, to propose a more limited planting programme to be undertaken over a much longer period of time

- continued planting a wide range of exotic timber species

- persisted with departmental efforts to grow indigenous timber trees in plantations (French foresters were planting on two hundred-plus year rotations)

- have regarded thinning and pruning as an essential part of the creation of the plantation forest estate (thus also creating options for a small-scale local industry based on posts, poles, and firewood)

- have thought in terms of timber demand and persisted with the idea of regional timber supply forests, especially in treeless regions (something Ellis moved away from after 1925)

- have looked at replanting suitable areas of cut-over indigenous forest with indigenous timber trees

- have interplanted exotic timber trees in some indigenous production forests

- have not concentrated so much of the planting effort on the Kaingaroa plains

- have given more attention to attempting to implement sustained-yield management of indigenous forests

- have promoted the small core of professionally trained foresters in due course to senior administrative positions

- have supported university forestry education in New Zealand (as did Ellis).

The last two are not unimportant considerations. A. D. McGavock, the Director of Forests (1932-38), a shrewd public servant but without any professional qualifications, was hostile to the proposition that there was any need for forestry graduates in the State Forest Service - this set-back for forestry may have been avoided. This also poses the question of whether A. R. Entrican, who was a dominant figure in the forestry sector as Director of Forests 1939-61, and an

82 Helen Beaglehole, Fire in the Hills: A History of Rural Fire-fighting in New Zealand (Christchurch: Canterbury University Press, 2012). 
Ellis appointee, would ever have been employed as Forest Engineer in 1921 by Director ' $\mathrm{X}$ '. With an ounce of luck Director ' $\mathrm{X}$ ' may also have favoured one site and the flawed, underfunded two-school model born of provincial jealousies inherent in the University of New Zealand system might have been avoided - but probably not, such was the provincial division among the university colleges. ${ }^{83}$

What would this have meant for the appearance of forestry in New Zealand? Arguably the down-stream significance would have been considerable. For instance, the pulp and paper industry would likely have developed earlier as an entirely private-sector initiative on the part of Whakatane Board Mills Ltd. and New Zealand Forest Products. The state plantations would have been more widely distributed and have contained a much wider range of exotic species that supported smaller regional sawmilling industries. It follows that there would have been a much smaller Kaingaroa Forest for the state to sell off the cutting rights to in the 1990s. Timber famine concerns may have reappeared in the immediate post-war period when the tensions between timber for housing and the sustained-yield targets would still have been compromised. It is also likely that a conflict between foresters and environmentalists would have gained expression sooner, possibly before World War II. The Waipoua kauri forest controversy was a defeat for sustained-yield forestry in 1949; this alternative scenario envisages earlier efforts by the foresters to achieve regeneration of indigenous forests and implement sustained-yield management. This might have seen a much earlier attempt to implement sustained-yield management of beech forests on the West Coast. It may also have produced larger-scale experiments of limited success in the remaining podocarp forests. The impetus that the Waipoua forest campaign generated could have escalated into a contest over the remaining indigenous forest. A political solution would have been especially vexed if the New Zealand Forest Service had not, by this time in this alternative scenario, planted sufficient exotic timber to meet domestic needs.

\section{Conclusion}

I would still cling to my earlier position that Ellis during his time as Director of Forests believed in the place of the state in the production and protection of forests and, in the long term, the provision of forest products, whereby sustained-yield management of natural forests remained central. The 300,000acre planting boom was a bold measure, initially intended to allay timber famine fears and provide time for the natural regeneration of indigenous forests to be understood, though I would now concede the idea of large-scale afforestation

83 Michael Roche and John Dargavel, 'Imperial Ethos, Dominions Reality: Forestry Education in New Zealand and Australia, 1910-1965', Environment and History 14 (2008), 523-43. 
was not so far outside the forestry canons as I had earlier believed (viz. the example of the British Forestry Commission), albeit on a reduced scale and over a longer time span, and with a different rationale. That said, Ellis was able to push ahead with such a grand afforestation project because suitable Crown land was available and crucially because the cost of planting per acre had been hugely reduced, which was a departure from the situation in Great Britain, thus also overcoming one of the orthodox forestry objections to large-scale afforestation. It was not plantation forestry per se, but the large planting target to be achieved in a decade that was especially notable. That so much of the planting effort took place at Kaingaroa, which was originally conceived to reach only 80,000 acres but expanded to 145,963 acres by 1930 is also worthy of attention. ${ }^{84}$ Also significant was the large-scale planting of Pinus radiata rather than a familiar European or North American plantation forest species. That it was then unknown whether Pinus radiata was really suitable for papermaking was also in keeping with Ellis' confidence. Ellis, incidentally, was fully aware of the difficulties he was bequeathing to a subsequent generation of foresters by not having a full ageclass distribution, but considered that it would be difficult to maintain political support for a 30-plus-year planting regime. If the indigenous forests had readily regenerated and been amenable to sustained-yield management, Ellis would still have been fascinated by the possibilities of large-scale afforestation in New Zealand, because trees grew so well and so quickly across the country, land was available, and there were new long-term possibilities for a wood export industry. The speed of growth particularly attracted his attention as it made forestry an investment option within an individual's lifetime - though he was thinking of farmers and small wood-lot owners, and not company plantationsbut long-term thinking, indigenous regeneration, and sustained yield would have remained central to his views.

The situation where secondary literature is now sufficient to allow revisionist questions to be posed about the environmental history of New Zealand is to be welcomed. My interpretation of state forestry in the first half of the twentieth century has differed from that of the historians Beattie and Star. This has prompted me here to reinterrogate some source material. In conclusion, this leads me to continue to argue that the historians' jump from nineteenth-century tree-planting to twentieth-century afforestation underplays the commitment of foresters to sustained-yield management of indigenous forests, albeit in a form that was to be thwarted in many ways.

But on the other hand, I would now acknowledge that Ellis' 1920-25 afforestation work used techniques and approaches similar to that of the United Kingdom, and was favourably commented on by Forestry Commission officials. 
Ellis' motivation for, and planning of, the 300,000-acre planting boom of 192534 also departed more from the forestry canon than I had previously appreciated, indicated by the reaction of the Empire foresters in 1928. Furthermore, Ellis also developed a personal enthusiasm for exotic afforestation that was notable for its scale and championing of the unproven Pinus radiata. But he actually departed from New Zealand only three years into his planting programme, which was taken to completion by his successors Phillips Turner and McGavock, neither of whom was a professionally trained forester. Depression tree-planting schemes also meant it exceeded the original target by around 25 per cent.

To some extent, my distance from the historians is a classic 'splitters' versus 'lumpers' argument; here the environmental historians are conscious of continuities, whereas my own position has been one that emphasises the discontinuity between older-style forest preservation as conservation and scientific state forestry, introduced to New Zealand by a new group of professionally trained expert natural resource managers in the 1910s and 1920s. Added to this is the situation where Beattie would likely position himself as an historian of the nineteenth century, whereas my own interests have swung rather towards the first decades of the twentieth century. One consequence of this is that the transition years from the end of the 'long nineteenth century' to the 'short' twentieth century, which are particularly important ones for forestry in New Zealand, can fall somewhat between the grasp of both of us. 
This text is taken from International Review of Environmental History, Volume 1, 2015, edited by James Beattie, published 2015 by ANU Press, The Australian National University, Canberra, Australia. 